\title{
Epidemiological Study of Iron Deficiency Anemia among Youth Female Athletes in Kuwait
}

\author{
${ }^{1}$ Mahmoud AlySaleh, ${ }^{1}$ AbdoSalamaAbdo, ${ }^{1}$ Rasha Shaker Eldesouky, ${ }^{1}$ Mona Ahmed \\ El-Awady, ${ }^{2}$ Mai Shaker Almaghrabi
}

${ }^{1}$ Publichealth and Community Medicine, Faculty of Medicine, Benha University, Egypt. ${ }^{2}$ Registrar in Sport medicine and Health awareness Center, Public authority for sport, Kuwait

Received: August, $2018 \quad$ Accepted: October, 2018

\begin{abstract}
Background The prevalence of iron deficiency anemia (IDA) is likely to be higher in athletic populations and groups, especially in younger female athletes, than in healthy sedentary individuals. Objective: to determine the magnitude of IDA among female athletes and identify correlated different dietary habits. Method: Across sectional study was carried out. The sample included 150 female players from the female clubs in Kuwait where almost all types of sports activity are practiced at the level of national competition. Data collection tools included structured assisted questionnaire with laboratory investigations. Results: $55 \%$ of anemic group were non-Kuwaiti, with a statistically significant difference. There was a statistically significant difference between the anemic, iron deficient and normal groups regarding the marital status, occupation, dietary pattern and habits as intake of tea and soft drinks. There were highly statistical significant differences between the three studied groups regarding mean corpuscular volume (MCV), mean corpuscular hemoglobin $(\mathrm{MCH})$, mean corpuscular hemoglobin concentration (MCHC) and serum ferritin. Logistic regression analysis reveals that increased number of soft drinks and tea drinks per day is significantly associated with high probability of having anemia. Women with increased consumption of soft drinks and tea per day are more than two times at higher risk of anemia $(\mathrm{OR}=2.34$ and 2.17 respectively). On the other hand, Kuwaiti nationality, increased duration of practicing sport and increased frequency of eating breakfast in the last month subjects are significantly associated with lower probability of having anemia $(\mathrm{OR}=0.14$, 0.74 and 0.17 respectively). Conclusion: More attention should be directed to athletic females with IDA.
\end{abstract}

Key words: Female athletes, iron deficiency, dietary iron, dietary pattern and habits

Corresponding author: Rasha Shaker Eldesouky Email: dr.rashashaker@gmail.com

\section{Introduction:}

Anemia is the most common disorder of the blood, affecting about quarter the people worldwide. ${ }^{1}$ Itis usually defined as a decrease in amount of red blood cells (RBCs) or hemoglobin in the blood., ${ }^{2,3}$ Iron-deficiency anemia is the most common type of anemia. It happens when the body does not have enough iron. Iron deficiency is typically due to blood loss but may infrequently be due to poor absorption of iron. Pregnancy and childbirth consume a great deal of iron and thus can cause pregnancy-related anemia. Individuals who have had gastric bypass surgery for weight reduction or other reasons may also be iron deficient due to weak absorption. ${ }^{4}$ female athletes are considered to be at a greater risk of compromised iron status which may lead to iron deficiency (with or without anemia) due to negative iron balance contributed by insufficient dietary iron 
intake, menstruation, increased iron losses associated with haemolysis, sweating, gastrointestinal bleeding and exercise induced acute inflammation. 5 , ${ }^{6}$ Not all women athletes are equally at risk for anemia. Risk factors include: recent child- birth, excessive menstrual flow, disadvantaged socioeconomic background, dietary restrictions such as vegetarian diet, weight loss diets, or fad diets, intense or prolonged endurance training, personal or family history of anemia, chronic disease, or bleeding disorders, use of anti-inflammatory medications, and recent blood donation. ${ }^{7}$ It is well recognized that vigorous physical activity results in an acute inflammatory response. Theoretically, the physiological effect of the acute phase reaction (APR) is to prepare the individual for probable battle by increasing the blood volume and the cardiac output, as well as mobilizing the coagulation system and avoiding bleeding. Many research groups have studied the inflammatory response related to physical activity and rational data from these groups point to a chain of action, from physical activity to the APR through several cytokines, such as IL-1, IL-6 and TNF- $\alpha$. Secondary to the IL-6 activity, raised levels of hepcidin, the main regulator of iron absorption the gut, and release from the macrophages are noted. ${ }^{8}$ Studies on athletes have shown an elevated level of inflammatory cytokines and of hepcidin after physical activity. In some studies, elevated levels were seen as long as 24 hours after the activity ${ }^{8}$ and in another, the levels were still elevated after 72 hours of rest. ${ }^{9}$ Iron plays an important role in oxygen transport and fuel consumption (10). Iron is crucial for the synthesis of hemoglobin and myoglobin, the proteins that carry oxygen to the blood and muscle, respectively. It is a vital component of the electron transport system that controls the energy release from cells. Iron is involved in DNA synthesis and red blood cell production. It acts as a promoter against harmful freeradical production. ${ }^{11}$ But still wondering how exactly this mineral affects peak physical performance and when an athlete functions without adequate iron, less oxygen is transported to the muscles, maximal oxygen consumption $\left(\mathrm{VO}_{2} \mathrm{max}\right)$ falls, and physical performance is affected. ${ }^{12}$ Moreover, too little iron may weaken immune and other physiological functions. ${ }^{13}$ Iron deficiency is a progressive condition that develops through three stages: iron depletion, iron deficiency and iron deficiency anemia. ${ }^{14}$ Iron deficiency is more common among physically active individuals compared with their sedentary counterpart. There are a few reasons why athletes are at a higher risk of experiencing iron deficiency compared to their non-athletic counterparts as higher requirements for iron use and increased risk of iron loss. ${ }^{15,16}$

The aim of this study was to determine the magnitude of the iron deficiency and iron deficiency anemia among female athletes in Kuwait and identify their different dietary habits.

\section{Method}

A cross sectional study was done. Based on recent figure about the prevalence of iron deficiency anemia (IDA) among female athletes to be $10 \%{ }^{17}$ the minimum sample size was calculated to be $139(\mathrm{~N}=$ $\mathrm{Z}^{2} \times \mathrm{PQ} / \mathrm{E}^{2}=(1.96)^{2} \times 0.10 \times 0.97 /(0.05)^{2}$ $=139$ ) out of the total 321 female athletes registered. The sample was increased to 150 players from the three female clubs in Kuwait (Aloyoun sport club, Salwa Alsabah sport club and Alfatat sport club) where almost all types of sports activity are practiced at level of national competition to increase accuracy of the results. Players fulfilling the inclusion criteria and accepted to participate were included. A random group of 150 female athletes were selected from a population of 321 using random systematic sampling 
technique. Table1: Prevalence of IDA, ID and being normal among studied groups

\begin{tabular}{|l|l|l|}
\hline $\begin{array}{l}\text { Groups } \\
\text { (no.=150) }\end{array}$ & No. & $\%$ \\
\hline $\begin{array}{l}\text { *IDA } \\
\text { (below normal Hb \& } \\
\text { below normal ferritin) }\end{array}$ & 22 & 14.7 \\
\hline
\end{tabular}

\begin{tabular}{|l|l|l|}
\hline $\begin{array}{l}* \text { ID } \\
\text { (normal Hb \& below } \\
\text { normal ferritin) }\end{array}$ & 55 & 36.7 \\
\hline $\begin{array}{l}\text { Normal } \\
\text { (normal Hb\& normal } \\
\text { ferritin) }\end{array}$ & 73 & 48.7 \\
\hline
\end{tabular}

IDA: Iron Deficiency Anemia, ID: Iron Deficient Hb: blood hemoglobin, * This criteria according to German et al, $(2015)^{19}$.

Table 2: Comparing IDA, ID and normal groups according to sociodemographic characteristics

\begin{tabular}{|c|c|c|c|c|c|c|c|c|c|}
\hline \multirow{2}{*}{ Variable } & & \multicolumn{2}{|c|}{$\begin{array}{l}\text { IDA } \\
(\text { no. }=22)\end{array}$} & \multicolumn{2}{|c|}{$\begin{array}{l}\text { ID } \\
(\text { no. }=55)\end{array}$} & \multicolumn{2}{|c|}{$\begin{array}{l}\text { Normal } \\
\text { (no.=73) }\end{array}$} & \multirow{2}{*}{$\begin{array}{l}\text { Chi } \\
\text { squared } \\
\text { test }\end{array}$} & \multirow[t]{2}{*}{$\mathrm{P}$} \\
\hline & & No. & $\%$ & No. & $\%$ & No. & $\%$ & & \\
\hline \multirow[b]{2}{*}{ Nationality } & Kuwaiti & 10 & 45.5 & 45 & 81.8 & 58 & 79.5 & \multirow[b]{2}{*}{12.48} & \multirow[b]{2}{*}{$<0.05$} \\
\hline & $\begin{array}{l}\text { Non- } \\
\text { Kuwaiti }\end{array}$ & 12 & 54.6 & 10 & 18.2 & 15 & 20.6 & & \\
\hline Age (years) & Mean \pm SD & \multicolumn{2}{|c|}{$18.95 \pm 3.41$} & \multicolumn{2}{|c|}{$18.8 \pm 3.05$} & \multicolumn{2}{|c|}{$18.54 \pm 2.86$} & $\mathrm{~F}=0.21$ & $>0.05$ \\
\hline \multirow[t]{2}{*}{ Marital status } & Single & 17 & 77.3 & 50 & 90.9 & 70 & 95.9 & \multirow{2}{*}{ FET } & \multirow{2}{*}{$<0.05$} \\
\hline & Married & 5 & 22.7 & 5 & 9.1 & 3 & 4.1 & & \\
\hline \multirow{5}{*}{$\begin{array}{l}\text { Educational } \\
\text { level }\end{array}$} & Primary & 1 & 4.6 & 0 & 0.0 & 0 & 0.0 & \multirow{5}{*}{ FET } & \multirow{5}{*}{$>0.05$} \\
\hline & intermediate & 4 & 18.2 & 3 & 5.5 & 3 & 4.1 & & \\
\hline & Secondary & 10 & 45.5 & 25 & 45.5 & 36 & 49.3 & & \\
\hline & Diploma & 5 & 22.7 & 9 & 16.4 & 17 & 23.3 & & \\
\hline & University & 2 & 9.1 & 18 & 32.7 & 17 & 23.3 & & \\
\hline \multirow{4}{*}{ Occupation } & Student & 11 & 50.0 & 44 & 80.0 & 58 & 79.5 & \multirow{4}{*}{ FET } & \multirow{4}{*}{$<0.05$} \\
\hline & No work & 7 & 31.8 & 4 & 7.3 & 2 & 2.7 & & \\
\hline & Employee & 2 & 9.1 & 3 & 5.5 & 6 & 8.2 & & \\
\hline & Technician & 2 & 9.1 & 4 & 7.3 & 7 & 9.6 & & \\
\hline
\end{tabular}

F: Oneway Analysis Of Variance (ANOVA); P: Probability ; Significant ( $P<0.05) ;$ Non-significant $(P>0.05)$ FET: Fisher Exact Test ; IDA: iron deficiency anemia ; ID: iron deficiency

A random group of 150 female athletes were selected from a population of 321 using systematic sampling, all the potential participants were placed in a list and a starting point was selected "started with the 1st one". Once the list was formed, every 2nd person "alternate" on the list was chosen as a participant, since $321 / 150=2.14$ till the sample size was completed.

Data were collected from the sample's athletes using a structured assisted questionnaire which included personal sociodemographic characteristics and history of following diet. In addition, dietary habits of the athletes, the components of athletes 'meals, as well as drinking tea, coffee and soft drinks.
Smoking, medical history, family medical history (as diabetes and hypertension) and gynecological history were also included. Finally, a detailed description of the practiced sport was reported. Physical examinations as anthropometric measurements (weight, height, waist circumference and calculating body mass index), medical examination which include blood pressure, signs of anemia, abdominal examination and blood investigations (18) (hemoglobin, MCV, $\mathrm{MCH}, \mathrm{MCHC}$ and serum ferritin).

The collected data were summarized in terms of mean \pm Standard Deviation (SD) and range for quantitative data and frequency and percentage for qualitative 
Table 3: Comparing IDA, ID and normal groups regarding the dietary pattern and habits

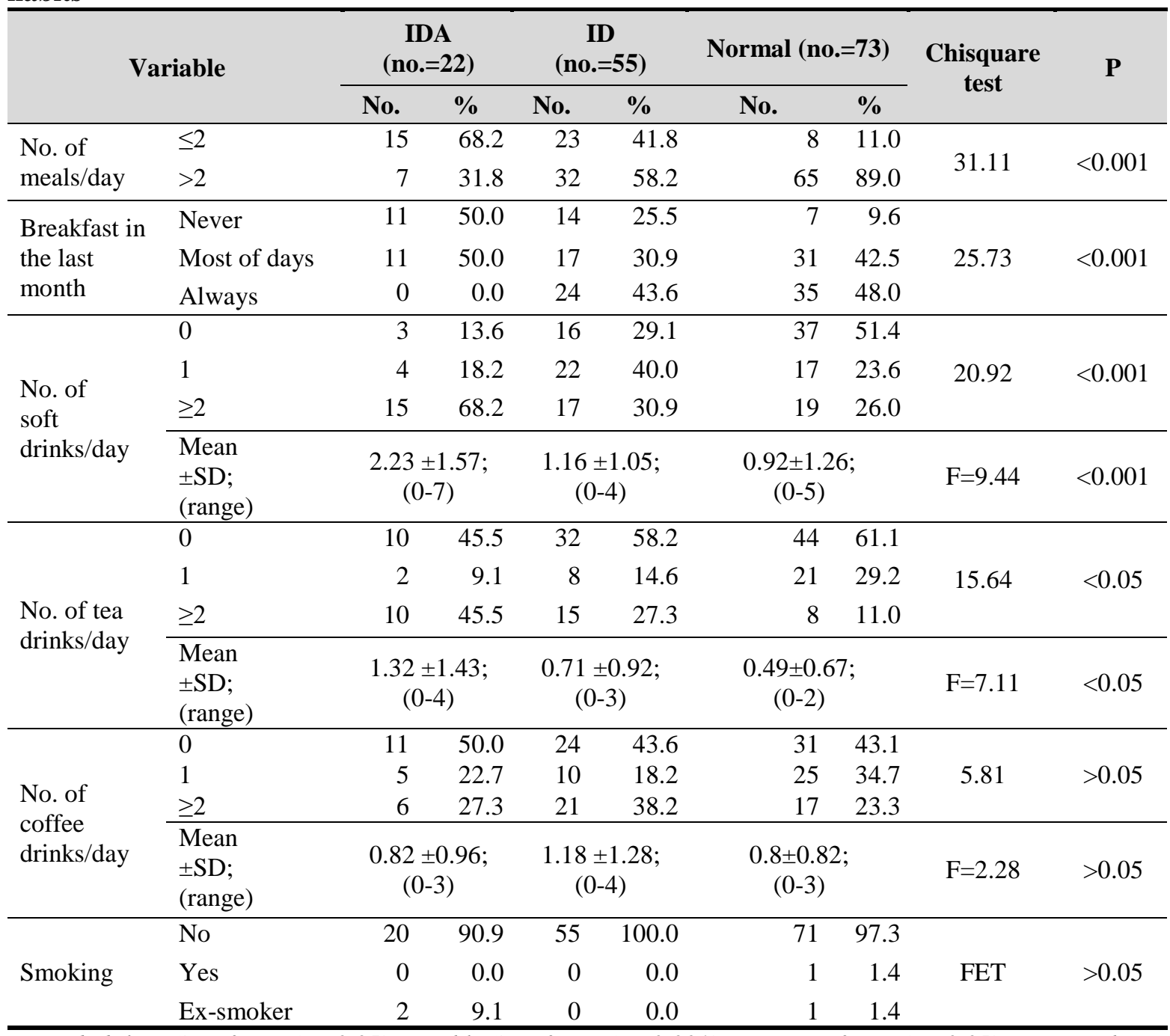

P: Probability; Significant $(P<0.05)$; Highly Significant $(P<0.001)$; Non-significant $(P>0.05) ;$ FET: Fisher Exact Test; F: Oneway Analysis Of Variance (ANOVA); IDA: Iron Deficiency Anemia; ID: Iron Deficient data. Comparisons between the different study groups were carried out using the Chi square $\left(\chi^{2}\right)$ and Fisher's Exact Test (FET) to compare proportions as appropriate. The student t-test $(t)$ was used to compare differences in the mean between two groups regarding normally distributed data. Stepwise logistic regression of being anemic conditioned on potential risk factors was carried out to identify significant predictors and the results were expressed as Odd Ratio (OR) and $95 \%$ Confidence Interval (CI). Statistical significance was accepted at $\mathrm{P}$ value $<0.05$ (S). A P value $<0.001$ was considered highly significant (HS) while a $\mathrm{P}$ value $>0.05$ was considered nonsignificant. All statistical analyses were carried out using STATA/SE version 11.2 for Windows (STATA Corporation, College Station, Texas).

\section{Results:}

The study revealed that $(14.7 \%)$ of the subjects included had a low hemoglobin value and low serum ferritin that were classified as being iron deficiency anemia (IDA). 36.7\% had a normal hemoglobin value and low serum ferritin that were classified as being iron deficient (ID) while the rest of the participants were classified as being normal (48.7\%) (Table 1).

Regarding the sociodemographic characteristic, more than half of anemic (54.6\%) were non-Kuwaiti. The majority 
Table 4: Comparing IDA, ID and normal groups according to dietary sources of iron (heme)

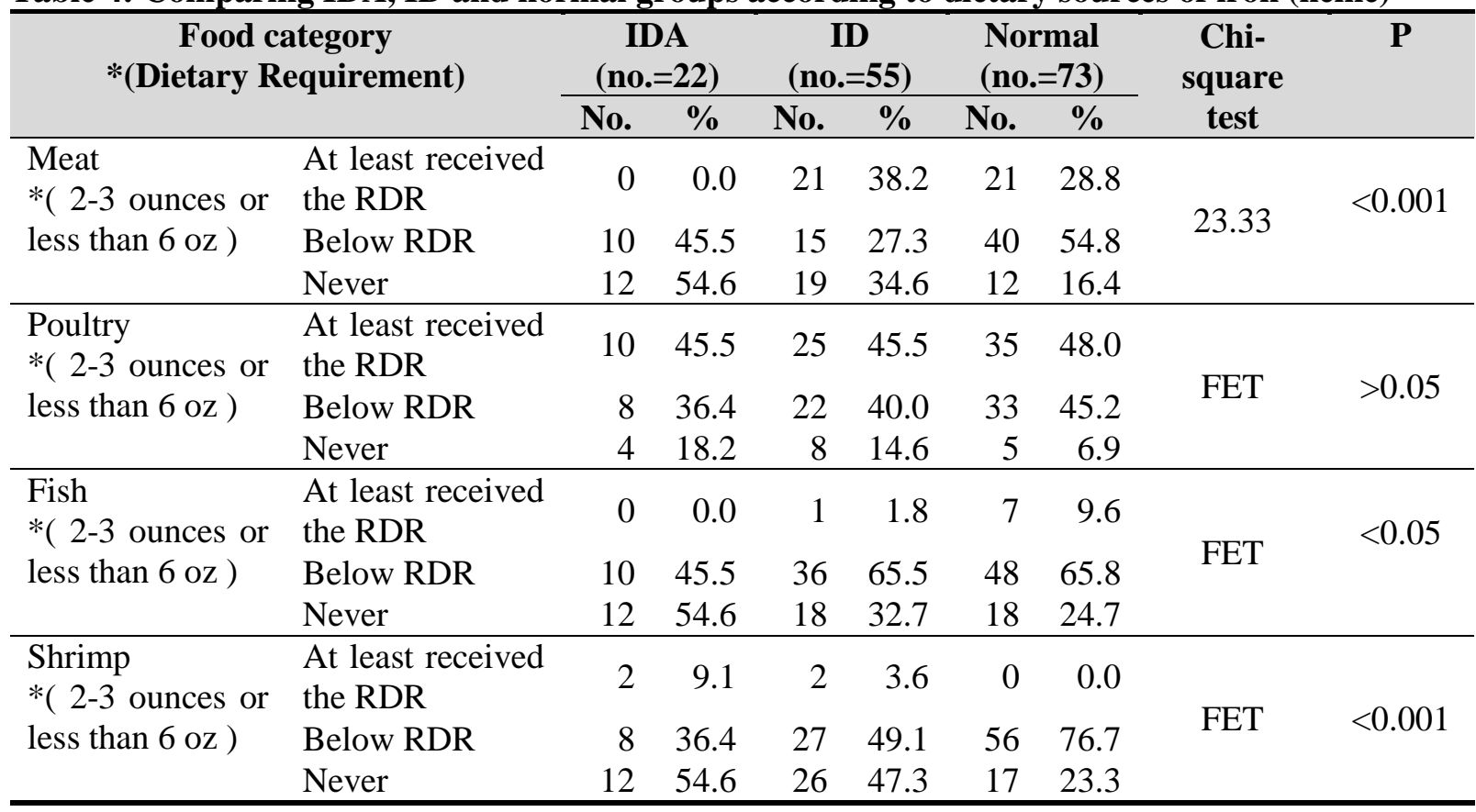

P: Probability; Significant $(P<0.05)$; Highly Significant $(p<0.001) ;$ FET: Fisher Exact Test; RDR: Recommended Dietary Requirement; IDA: Iron Deficiency Anemia; ID: Iron Deficient ; * This criteria according to United States Department of Agriculture (USDA) (2005) $)^{20}$

of iron deficient $(81.8 \%)$ and of normal $(79.5 \%)$ were Kuwaiti with statistically significant difference $(\mathrm{P}<0.05)$. There was a statistically significant difference between the three groups regarding the marital state and occupation $(\mathrm{P}<0.05)$ for all but insignificant difference regarding the mean age and the educational level ( $\mathrm{P}>0.05$ ) (Table 2).

Regarding the dietary pattern and habits between the three groups more than two thirds $(68.2 \%)$ of the iron deficient anemic participants had two or less meals per day while more than half of iron deficient group (58.2\%) compared to the majority of normal athletes (89\%) consumed more than two meals per day. This difference is statistically significant $(\mathrm{P}<0.001)$ (Table 3).

Table 3 also shows that exactly half $(50 \%)$ of the IDA group never had breakfast and the other half had breakfast most of the days in last month. In the iron deficient and normal groups, the highest percentage for those who always had breakfast in the last month (43.6\% and 48\% respectively). This difference is statistically significant $(\mathrm{P}<0.001)$. There was a highly statistically significant difference regard the number of soft drinks $(\mathrm{P}<0.001)$ and tea cups consumed daily $(\mathrm{P}<0.05)$.

Table 4 reveals that more than half of the anemic participants $(54.6 \%)$ did not eat meat or shrimp, with statistically highly significant difference between the studied groups $(\mathrm{P}<0.001)$.

The menstrual history shows insignificant difference between the three groups regarding the age of menarche, regularity, the duration or amount of menstrual bleeding (Table 5). A highly statistical significant differences between the anemic, iron deficient and normal groups regarding blood hemoglobin $(\mathrm{Hb})$, Mean corpuscular volume (MCV), Mean corpuscular hemoglobin (MCH), Mean corpuscular hemoglobin concentration $(\mathrm{MCHC})$ and Serum ferritin $(\mathrm{P}<0.001$ in all items). The mean hemoglobin $(\mathrm{Hb})$ level among the IDA group was $11.07 \pm 0.63 \mathrm{gm} / \mathrm{dl}$ while it was $13.03 \pm 0.98 \mathrm{gm} / \mathrm{dl}$ among ID group and $13.41 \pm 0.78 \mathrm{gm} / \mathrm{dl}$ among normal group. Regard the mean serum ferritin level among IDA, ID and normal participants was $12.01 \pm 6.13 \mathrm{ng} / \mathrm{ml}, 18.87 \pm 6.04$ 
Table 5: Comparing IDA, ID and normal groups according tohistory of the menestrual cycle

\begin{tabular}{|c|c|c|c|c|c|c|c|c|c|}
\hline \multirow{2}{*}{\multicolumn{2}{|c|}{ Variables }} & \multicolumn{2}{|c|}{$\begin{array}{c}\text { IDA } \\
\text { group } \\
\text { (no.=22) }\end{array}$} & \multicolumn{2}{|c|}{$\begin{array}{l}\text { ID group } \\
(\text { no.=55) }\end{array}$} & \multicolumn{2}{|c|}{$\begin{array}{c}\begin{array}{c}\text { Normal } \\
\text { group } \\
(\text { no. }=73)\end{array} \\
\end{array}$} & \multirow{2}{*}{$\begin{array}{l}\text { Chi- } \\
\text { square } \\
\text { test }\end{array}$} & \multirow[t]{2}{*}{$\mathbf{P}$} \\
\hline & & No. & $\%$ & No. & $\%$ & No. & $\%$ & & \\
\hline $\begin{array}{l}\text { Age of } \\
\text { menarche } \\
\text { (years) }\end{array}$ & $\begin{array}{l}\text { Mean } \pm \text { SD } \\
\text { (range) }\end{array}$ & \multicolumn{2}{|c|}{$\begin{array}{c}11.14 \pm 1.32 \\
(9-13)\end{array}$} & \multicolumn{2}{|c|}{$\begin{array}{c}11.78 \pm 1.64 \\
(9-15)\end{array}$} & \multicolumn{2}{|c|}{$\begin{array}{c}11.46 \pm 1.52 \\
(9-15)\end{array}$} & $\mathrm{F}=1.53$ & $>0.05$ \\
\hline \multirow{2}{*}{$\begin{array}{l}\text { Regularity of } \\
\text { menses }\end{array}$} & Yes & 14 & 63.6 & 42 & 76.4 & 58 & 79.5 & \multirow{2}{*}{2.32} & \multirow{2}{*}{$>0.05$} \\
\hline & No & 8 & 36.4 & 13 & 23.6 & 15 & 20.6 & & \\
\hline $\begin{array}{l}\text { Duration of } \\
\text { period (days) }\end{array}$ & $\begin{array}{l}\text { Mean } \pm \text { SD } \\
\text { (range) }\end{array}$ & \multicolumn{2}{|c|}{$\begin{array}{c}5.91 \pm 1.06 \\
(4-7)\end{array}$} & \multicolumn{2}{|c|}{$\begin{array}{l}5.62 \pm 1.21 \\
(2-7)\end{array}$} & \multicolumn{2}{|c|}{$\begin{array}{c}5.74 \pm 1.11 \\
(3-7)\end{array}$} & $\mathrm{F}=0.53$ & $>0.05$ \\
\hline \multirow{3}{*}{$\begin{array}{l}\text { Amount of } \\
\text { blood } \\
\text { (no of } \\
\text { pads/day) }\end{array}$} & $\begin{array}{l}\text { Minimum } \\
(<3)\end{array}$ & 3 & 13.6 & 6 & 10.9 & 8 & 11.0 & \multirow{3}{*}{ FET } & \multirow{3}{*}{$>0.05$} \\
\hline & $\begin{array}{l}\text { Average } \\
(3-6)\end{array}$ & 15 & 68.2 & 42 & 76.4 & 59 & 80.8 & & \\
\hline & $\begin{array}{l}\text { Excessive } \\
(>6)\end{array}$ & 4 & 18.2 & 7 & 12.7 & 6 & 8.2 & & \\
\hline
\end{tabular}

P: Probability; FET: Fisher Exact Test; F: Oneway Analysis Of Variance (ANOVA); IDA: Iron Deficiency Anemia; ID: Iron Deficient; Non-significant $(P>0.05)$

Table 6: Comparing IDA, ID and normal groups according to the different laboratory investigations

\begin{tabular}{|c|c|c|c|c|c|c|c|c|c|c|c|}
\hline \multirow[t]{2}{*}{ Variable } & \multicolumn{2}{|c|}{$\begin{array}{c}\text { IDA } \\
(\text { no.=22) }\end{array}$} & \multicolumn{4}{|c|}{$\begin{array}{c}\text { ID } \\
(\text { no. }=55)\end{array}$} & \multicolumn{2}{|c|}{$\begin{array}{l}\text { Normal } \\
(\text { no. }=73)\end{array}$} & \multirow[b]{2}{*}{ Range } & \multirow[t]{2}{*}{$\mathbf{F}$} & \multirow[t]{2}{*}{$\mathbf{P}$} \\
\hline & Mean & SD & Range & Mean & SD & Range & Mean & SD & & & \\
\hline $\begin{array}{l}\text { HB } \\
(\mathrm{gm} / \mathrm{dl})\end{array}$ & 11.07 & 0.63 & $10-11.9$ & $\dagger 13.03$ & 0.98 & $12-15.3$ & $\dagger+13.41$ & 0.78 & $12-15.3$ & 65.41 & $<0.001$ \\
\hline $\begin{array}{l}\text { MCV } \\
\text { (fl) }\end{array}$ & 74.7 & 5.2 & $67-88.5$ & $\uparrow 84.8$ & 4.69 & $76.7-93.5$ & $\dagger 86.05$ & 3.4 & 78.7-94 & 63.27 & $<0.001$ \\
\hline $\begin{array}{l}\mathrm{MCH} \\
\text { (pg) }\end{array}$ & 24.7 & 2.23 & $21.5-30$ & $\dagger 30.05$ & 7.95 & $24-86.4$ & $\dagger 29.22$ & 1.67 & $26.3-33.3$ & 8.95 & $<0.001$ \\
\hline $\begin{array}{l}\mathrm{MCHC} \\
(\mathrm{gm} / \mathrm{l})\end{array}$ & 326.8 & 5.31 & $\begin{array}{l}317- \\
337\end{array}$ & $\dagger 335.87$ & 7.92 & $313-351$ & $\dagger 337.42$ & 8.01 & $309-352$ & 16.45 & $<0.001$ \\
\hline $\begin{array}{l}\text { Serum } \\
\text { ferritin } \\
(\mathrm{ng} / \mathrm{ml})\end{array}$ & 12.0 & 6.13 & $4-31.2$ & $\dagger 18.87$ & 6.04 & $9-29.8$ & $\dagger+43.38$ & 12.67 & $30-77$ & 138.19 & $<0.001$ \\
\hline
\end{tabular}

P: Probability; Significant $(P<0.05)$; Highly Significant $(P<0.001) ; F$ : Oneway Analysis Of Variance $($ ANOVA $)+$ Significant differences compared to anemic group; $\neq$ Significant differences compared to iron deficient group

Table 7: Logistic regression analysis for being anemic athletes conditioned on significant risk factors

\begin{tabular}{llll}
\hline Variable (no.=150) & OR & $\mathbf{9 5 \%}$ CI & P \\
\hline $\begin{array}{l}\text { Nationality } \\
\text { (Kuwaiti } v \text { s. non-Kuwaiti) }\end{array}$ & 0.14 & 0.04 to 0.53 & 0.003 \\
\hline Duration of practicing sport (years) & 0.74 & 0.58 to 0.96 & 0.02 \\
\hline $\begin{array}{l}\text { Eating breakfast in the last month* } \\
\text { (never/most of days/ always) }\end{array}$ & 0.17 & 0.06 to 0.48 & 0.001 \\
\hline No. of soft drinks/day & 2.34 & 1.43 to 3.84 & 0.001 \\
\hline No. of tea drinks/day & 2.17 & 1.23 to 3.84 & 0.008 \\
\hline
\end{tabular}


* A continuous variable was used to indicate a trend; OR: Odd Ratio; 95\% CI: 95\% Confidence Interval $\mathrm{ng} / \mathrm{ml}$ and $43.38 \pm 12.67 \mathrm{ng} / \mathrm{ml}$ respectively (Table 6). All participants of the anemic and non-anemic groups had normal CRP levels (CRP negative).

All factors found to be significantly associated with the high risk of being anemic among female athletes were examined by multivariate stepwise logistic regression analysis, only significant predictors are shown in the output. Results of the logistic regression analysis reveal that increased number of soft drinks and tea drinks per day is significantly associated with high probability of having anemia. Women with increased consumption of soft drinks per day and those with high tea consumption per day are more than two times at higher risk of anemia $(\mathrm{OR}=2.34$ and 2.17 respectively). On the other hand, Kuwaiti nationality, increased duration of practicing sport and increased frequency of eating breakfast in the last month subjects are significantly associated with lower probability of having anemia $(\mathrm{OR}=0.14,0.74$ and 0.17 respectively) (Table 7).

\section{Discussion}

From the total female athletes aged (15$25)$, engaged in this research $(36.7 \%)$ had ID, (14.7\%) had ID anemia and (48.7\%) were normal. No previous studies done on female athletes in Kuwait to determine the prevalence of ID or IDA, it is the first study done to determine the magnitude of this problem among athletes. In 2015, a study assessed the prevalence of anemia and iron deficiency of a nationally representative sample of the Kuwait population but not athletes, reported that ID and IDA are prevalent in Kuwait. ${ }^{21}$

A significant percentage $(54.6 \%)$ of anemic female athletes included in this study were non Kuwaiti $(\mathrm{P}<0.001)$. Similar work done in $2004^{22}$ reported that the race plays a role in developing iron deficiency anemia.

A significant percentage $(81.8 \%)$ of Kuwaiti participants had only iron deficient compared to non-Kuwaiti. Many studies documented that the incidence of iron deficiency without anemia is greater in female athletes. ${ }^{22-24}$ Firstly, the Kuwaiti's habits of intake fast food and food that inhibits iron absorption as milk and milk products ${ }^{(21)}$. Secondary, the fact that iron absorption, which occurs mostly in the jejunum, is only 5 to $10 \%$ of dietary intake in persons in homeostasis, in states of overload absorption decreases. ${ }^{23}$ Also, Kuwaiti's food supply is widely available and highly subsidized.

Excessive calories are widely consumed, as evidenced by the estimated $40 \%$ obesity rate for Kuwait and it is often poor in iron. ${ }^{24}$ The marital state and occupation had a significant relation $(\mathrm{P}<0.05$ each) and insignificant relation between the level of education $(\mathrm{P}>0.05)$ and the IDA, ID and normal groups. These factors reflect the psychological and the social state of the participant females which in turn affect their dietary habits and predisposing to ID and IDA. These results are in agreement with similar work done in $2004^{25}$ by Jolie reported a positive relation between anemia, education level and occupation. On the contrary, a study done in Kuwait (26) reported that the prevalence of anemia and ID did not differ by level of education or income. Also there was no significant relation between ID, IDA or normal and age of the participants $(\mathrm{P}>0.05)$. However, a study done in Bangladesh in 2005 showed that the prevalence of anemia varied by age and gender, but not socioeconomic status. $^{27}$

The study shows a significant good iron state and iron intake, assessed as the number of meals per day and the frequency of eating breakfast, in the nonanemic athletes $(\mathrm{P}<0.001)$ each. ID and IDA in the anemic group is due to the change of their dietary pattern, as there was insignificant difference between the three groups regarding the history of other diseases. Also, a significant difference between IDA and ID athletes and the non-

Vol. 37 No. 3 July 2019


anemic group, regarding consumption the non heme iron and heme iron inhibitors or enhancers. Dietary iron occurs in two forms: haem and non-haem. The haem form of iron refers to iron from animal sources, whilst non-haem iron accounts for all other types of dietary iron. Haem iron is present within haemoglobin or myoglobin molecules and is released by proteolytic enzymes in the lumen of the stomach and the small intestine. ${ }^{28}$ As haem iron absorption does not require binding proteins, its uptake can be as efficient as $40 \%{ }^{(13)}$. However, it should be noted, that haem iron constitutes only about $10 \%$ of all dietary iron. ${ }^{28}$ Non-haem iron is bound to other food components and is usually present in ferric form. In order for it to be used by the body it must be reduced to ferrous iron by either brush border membrane enzymes or dietary reducing agents and transported by the divalent metal transporter into the enterocyte. ${ }^{28}$ Non-haem iron absorption depends on the levels of inhibitors and enhancers, hence, the availability of this form of iron varies greatly from 2 to $20 \%{ }^{13}$ Many researches explained the prevalence of ID and IDA in sport individuals is due to dietary pattern. ${ }^{29-32}$

The incidence of anemia is similar in anemic and non-anemic participants across all sports with insignificant difference between the two groups regarding the duration and time of practicing the sport. Supported by the work done by Haff and Triplett in 2015. ${ }^{33}$ On the contrary, other studies reported anemia more in runners and football players ("foot strike hemolysis"). ${ }^{34,35}$

A highly statistical significant differences between the three groups were found regarding blood hemoglobin $(\mathrm{Hb}), \mathrm{MCV}$, $\mathrm{MCH}$ and $\mathrm{MCHC}(\mathrm{P}<0.001)$ for all items indicating the presences of hypochromic microcytic anemia. Sport anemia that occurs in trained athletes, particularly in endurance sports because athletes have an increased total mass of red blood cells and hemoglobin in circulation relative to sedentary individuals. For defining anaemia, the cut off level of $120 \mathrm{~g} / \mathrm{L}$ set by the World Health Organization $2004^{36}$ using $\mathrm{Hb}$ level in combination with erythrocyte indices $(\mathrm{MCV}, \mathrm{MCH}$ and $\mathrm{MCHC}){ }^{37}$

\section{Conclusion}

IDA is more prevalent in non-Kuwaiti athletes that may be related to racial factors. ID and IDA are associated mainly with the dietary habits of the participants, the number of meals per day, the frequency of eating breakfast and type of food consumed.

\section{Recommendations}

Regular sessions of health education for athletic females about iron deficiency anemia, factors enhancing and inhibiting it together with annual screening for all female athletes, using the traditional markers for ID and IDA; hemoglobin, $\mathrm{MCV}, \mathrm{MCH}, \mathrm{MCHC}$, serum ferritin and TIBC are mandatory.

\section{References:}

1. McLean E, Cogswell M, Egli I, Wojdyla D and de Benoist B. (2009): Worldwide prevalence of anaemia, WHO Vitamin and Mineral Nutrition Information System, 19932005. Public Health Nutr;12 (4):444-454.

2. Rodak FB, Fritsma GA and Keohane E. (2007): Hematology: clinical principles and applications (3rd ed.). Philadelphia: Saunders. p. 220.

3. Stedman, Thomas Lathrop.(2006). Stedman's medical dictionary (28thed.). Philadelphia: Lippincott Williams \& Wilkins. 4. Kumar V, Abbas A K, Fausto N and Mitchell RN (2007): Robbins Basic Pathology (8th ed.). Saunders Elsevier. p. 432 ISBN 978-1-4160-2973-1.

5. McClung JP, Gaffney-Stomberg E, Lee JJ (2014): Female athletes: a population at risk of vitamin and mineral deficiencies affecting health and performance. J Trace Elem Med Biol;28(4):388-392.

6. Clenin GE, Cordes $M$, Huber A, Schumacher YO, Noack P, Scales J and Kriemler S. (2015): Iron deficiency in sports-definition, influence on performance 
and therapy. Swiss Med Wkly;145: 1-15 doi: 10.4414/smw.2015.

7. Sacirović, S., Asotic, J., Maksimovic, R., Radevic, B., Muric, B., Mekic, H., \&Biocanin, R. (2013). Monitoring and prevention of anemia relying on nutrition and environmental conditions in sports.Materia socio-medica, 25(2), 136.

8. Roecker, L., Meier-Buttermilch, R., Brechtel, L., Nemeth, E., \&Ganz, T. (2005). Iron-regulatory protein hepcidin is increased in female athletes after a marathon. European journal of applied physiology, 95(5-6), 569571.

9. Ziemann, E., Kasprowicz, K., Kasperska, A., Zembroń-Lacny, A., Antosiewicz, J., \&Laskowski, R. (2013). Do high blood hepcidin concentrations contribute to low ferritin levels in young tennis players at the end of tournament season?.Journal of sports science \& medicine, 12(2), 249-58.

10. Schumacher YO, Schmid A, Konig D and Berg A.(2002):Effects of exercise on soluble transferrin receptor and other variables of the iron status. Br J Sports Med ;36(3):195-199.

11. Burke, L. and Deakin, V.(2015): Clinical Sports Nutrition. 2000Australia: McGrawHill.

12. Rockwell, M., \& Hinton, P. (2005). Understanding iron. Training \& Conditioning, 15(8), 19-25.

13. Beard J and Tobin B.(2000): Iron status and exercise. Am J of Clin Nutr.;72(2):594s. 14. Janz, TG; Johnson, RL and Rubenstein, SD (2013): "Anemia in the emergency department: evaluation and treatment.".Emergency medicine practice 15 (11): 1-15.

15. Alaunyte L, StojceskaV and Plunkett A (2015): Iron and the female athlete: a review of dietary treatment methods for improving iron status and exercise performance. Journal of the International Society of Sports Nutrition 12:38

16. Cappellini A, Motta I,(2015): Anemia in Clinical Practice-Definition and Classification: Does Hemoglobin Change With Aging .Semin Hematol;52(4):261269.

17. Rowland T. (2012): Iron deficiency in athletes: an update. Am J Lifestyle Med. 6:319-327.

18. Mikhail N, Shea S, Raskova J and Skvara FC. (2005): Case-Based Pathology and Laboratory Medicine; Blockwell publishing, P1-2.
19. Clénin G E, Cordes M, Huber A, Schumacher YO, Noac P, Scales $J$ and Kriemler S (2016): Iron deficiency in sports definition, influence on performance and therapy Review article |: Swiss Sports \& Exercise Medicine; 64 (1): 6-18.

20. The United States Department of Agriculture (USDA) (2005): the food guide pyramid. https://www.cnpp.usda.gov/foodguide-pyramid-professionals. Last accessed 24 Sep 2017.

21. Al Zenki S, Alomirah $\mathrm{H}, \mathrm{Al}$ Hooti S, Al Hamad N, Jackson RT, Rao A, Al Jahmah N, Al Obaid I, Al Ghanim J, Al Somaie M, Zaghloul S and Al Othman A (2015): Prevalence and Determinants of Anemia and Iron Deficiency in Kuwait. Int J Environ Res Public Health;12(8):9036-9045.

22. Ramakrishnan U, Frith-Terhune A, Cogswell M, Kettel Khan L (2002): Dietary intake does not account for differences in low iron stores among Mexican American and non-Hispanic white women: Third National Health and Nutrition Examination Survey, 1988-1994. J Nutr;132(5): 996-1001.

23. Killip S, , Bennett J M. and Chambers MD. (2007): Iron Deficiency Anemia American Academy of Family Physicians; 75(5):671-678.

24. Ahmed F., Al-Somaie M. A. (2010). Iron deficiency and iron deficiency anemia among pregnant women in Kuwait. Int. J. Food Sci. Nutr;62:585-592. doi: 10.3109/09637486.2011.566848.

25. Holschen, J. C. (2004). The female athlete. Southern medical journal, 97(9), 852859.

26. Ramadan J., Vuori I., Lankenau B., Schmid T., Pratt M (2010): Developing a national physical activity plan: The Kuwait example. Glob. Health Promot;17(2):52- 57. doi: $10.1177 / 1757975910365230$.

27. Ahmed F., Khan M.A., Akhtaruzzaman M., Karim R., Marks G.C., Banu C.P., Nahar B., Williams G. (2005): Efficacy of twiceweekly multiple micronutrient supplementation for improving the hemoglobin and micronutrient status of anemic adolescent schoolgirls in Bangladesh. Amer. J. Clin. Nutr. 82(4):829-835.

28. Beard, J., \& Han, O. (2009). Systemic iron status. BiochimicaetBiophysicaActa (BBA)-General Subjects, 1790(7), 584-588.

29. Latunde-Dada GO (2013): Iron metabolism in athletes- achieving a gold 
standard. Eur J Haematol. 90(1):10-15. doi:10.1111/ejh.12026.

30. De Andrade Cairo RC, Rodrigues Silva L, CarneiroBustani $\mathrm{N}$ and Ferreira Marques $\mathrm{CD}$ (2014): Iron deficiency anemia in adolescents; a literature review. Nut.Hosp.; .29 (6): $1240-1249$. doi: $10.3305 / \mathrm{nh}$. 2014.29.6.7245.

31. Sinclair LM and Hinton PS (2005): Prevalence of iron deficiency with and without anemia in recreationally active men and women. J Am Diet Assoc;105(6):975978.

32. Leonard AJ, Chalmers KA, Collins CE and Patterson AJ (2014): A Study of the Effects of Latent Iron Deficiency on Measures of Cognition: A Pilot Randomised Controlled Trial of Iron Supplementation in Young Women, Nutrients;6(6): 24192435. doi: 10.3390/nu6062419.

33. Haff, G. G., \& Triplett, N. T. (Eds.). (2015). Essentials of strength training and conditioning 4 th edition. Human kinetics.
34. Dubnov G, Constantini NW (2004): Prevalence of iron depletion and anemia in top-level basketball players. Int J Sport NutrExercMetab 14(1):30-37.

35. Muneshwar J, Baig M, Kaderkar D, Khan S andiDeshmane H . (2013): Assessment of anaemia in football players: An observational Study. IOSR Journal of Dental and Medical Science (IOSRJDMS).; 8(5):64-66.

36. World Health Organization TUNCsF, United Nations University. (2004). Iron deficiency anaemia: assessment, prevention, and control. Retrieved from URL:http//www.who.int/nut/documents/ida assessment_prevention_control.pdf, accessed on 27 July 2018.

37. Pasricha SR, Low M, Thompson J, Farrell A and De-Regil LM. (2014): Iron Supplementation benefits physical performance in women of reproductive age: a systematic review and meta-analysis. J Nut ;144(6):906-914. 